\title{
0 budućnosti umirovljenika u post-pandemijskoj Hrvatskoj: može li potrošački stečaj biti jedno od rješenja? ${ }^{1}$
}

\section{Dejan Bodul}

Sveučilište u Rijeci, Pravni fakultet, Katedra za Građansko postupovno

pravo, Hrvatska

e-mail:dbodul@pravri.hr

\section{Marko Tomljanović}

Sveučilište u Rijeci, Ekonomski fakultet, Katedra za Međunarodnu

ekonomiju, Hrvatska

e-mail: marko.tomljanovic@efri.hr

SAŽETAK Temelj socijalne države čini sustav socijalne zaštite i sigurnosti. U operativno-metodološkom kontekstu radi se o troškovima socijalne sigurnosti. Jedna od najvećih stavki odnosi se na mirovine, kao (naj)veće komponente ukupnih izdataka za socijalne prestacije u svim zemljama Europske unije, pa tako i u Republici Hrvatskoj. Namjera rada nije ulaziti u analizu postojećeg mirovinskog sustava, namjera je konstatirati da pritisak davanja za mirovine uvjetovan pogoršanjem odnosa broja zaposlenih i broja umirovljenika nije zaobišao ni Republiku Hrvatsku, što je rezultiralo novim izazovima i pitanjima koje treba riješiti. Jedno od pitanja koje je predmet rada jest može li potrošački stečaj kao mjera sa socijalnim obilježjem kompenzirati negativne posljedice većeg broja umirovljenika i manjih mirovina u slučaju da se kod starijih osoba javi potreba za njegovim pokretanjem.

Ključne riječi: osiguranici prava na mirovinu, potrošačko-stečajni razlog, postupak potrošačkog stečaja, diskriminacija.

${ }^{1}$ Ovaj rad financiran je sredstvima Sveučilišta u Rijeci za projekt ZP UNIRI 4/19. 


\section{Metodologija rada}

Rad je podijeljen u sedam poglavlja. U cilju što sveobuhvatnije analize teme, nakon prikaza metodologije rada (poglavlje 1), u poglavlju 2 i 3 definiraju se pojmovi te se naznačuje znanstveni doprinos rada.

U poglavlju 4 provedena je deskriptivna analiza ključnih pokazatelja stanovništva starijega od 65 godine u Republici Hrvatskoj (dalje: RH) i zemljama članicama EU-a. Analiza je temeljena na sekundarnim podacima prikupljenima iz statističke baze Eurostat, pri čemu je, ovisno o dostupnosti podataka, obuhvaćeno razdoblje od 2009. do 2018. godine. U slučaju RH u radu su analizirani sljedeći indikatori: 1) udio stanovnika starijih od 65 godina (\% ukupnog stanovništva), 2) izdaci za mirovine (\% BDP-a), 3) izdaci za socijalnu zaštitu (\% BDP-a), 4) broj primatelja mirovina, 5) stanovništvo u riziku od siromaštva i socijalne isključenosti (\% stanovnika 65 i starijih), 6) prosječni godišnji raspoloživi dohodak stanovništva od 65 godina i starijeg (u eurima) te 7) iznos mirovina po stanovniku (u eurima). U slučaju zemalja članica EU-a analizirani su 1) udio stanovnika starijih od 65 godina (\% ukupnog stanovništva), 2) stanovništvo u riziku od siromaštva i socijalne isključenosti (\% stanovnika 65 i starijih), 3) prosječni godišnji raspoloživi dohodak stanovništva od 65 godina i starijeg (u eurima), 4) iznos mirovina po stanovniku (u eurima) te 5) dohodovna nejednakost starijeg stanovništva (od 65 godina i starijeg).

U sljedećem poglavlju daje se komparativni pregled institucionalnih okvira potrošačkog stečaja, kao korisne podloge za razmatranja vezana za države članice, ali i šire.

U poglavlju 6 analiziraju se zakonski propisi te domaća sudska praksa vezano za položaj umirovljenika u postupku stečaja potrošača. Pritom se ne zanemaruje činjenica složenosti institucionalnih i izvaninstitucionalnih mjera kao i posebnog normativnog okvira za promociju prava starijih osoba.

Naglasak je stavljen i na analizu judikature Europskog suda za ljudska prava (dalje: ECHR) u postupcima prema čl. 14. Europske konvencije za zaštitu ljudskih prava i temeljnih sloboda (Zabrana diskriminacije) jer polazimo od pretpostavke da saznanja o tome mogu biti ključna za razumijevanje problematike rada.

U zaključnim razmatranjima sintetiziraju se nalazi normativne i statističko deskriptivne analize ukazujući pritom na kompleksnost problema te paralelno inicirajući dijalog o odgovarajućim izmjenama Zakona o stečaju potrošača. 


\section{Osnovni pojmovi}

Imajući u vidu kompleksnost problema koji u ovom radu obrađujemo, a radi preciznosti i jasnoće, smatramo značajnim ab initio dati objašnjenje pojmova „osiguranik prava na mirovinu“ $i$,potrošački stečaj”.

Osiguranici prava na mirovinu osobe su kojima se na načelima uzajamnosti i solidarnosti obvezno osiguravaju prava za slučaj starosti i smanjenja radne sposobnosti uz preostalu radnu sposobnost, djelomičnog ili potpunog gubitka radne sposobnosti, a članovima njihovih obitelji prava za slučaj smrti osiguranika, odnosno korisnika mirovine (čl. 2. Zakona o mirovinskom osiguranju). Ipak, spuštajući se na praktičnu i empirijsku razinu, možemo tvrditi kako tako definiran tradicionalni „bizmarkov“ sustav ima i mnogo problema, pa umjesto stabilnosti empirijska analiza pokazuje da sustav nije samoodrživ te da osiguranici prava na mirovinu ne mogu biti sigurni da će primiti odgovarajući dohodak u starosti. Tomu su još doprinijeli i negativni demografski, ekonomski i socijalni trendovi.

$S$ druge strane, iako je proveden niz reformi stečajne legislative, dugo je smatrano kako ne postoje uvjeti za uvođenje posebne vrste stečajnog postupka za sve fizičke osobe. Stoga je doktrina prijašnje rješenje, stečaj nad imovinom dužnika pojedinca (trgovca pojedinca i obrtnika), do implementacije Zakona o stečaju potrošača 2015. godine (dalje ZSP) smatrala „tranzicijskom“ kategorijom. Ipak, stečajni postupak nad imovinom dužnika pojedinca kako je uređen u starom Stečajnom zakonu predstavljao je prvi korak prema mogućnosti provođenja stečajnog postupka nad imovinom svih fizičkih osoba, odnosno uvođenja potrošačkog stečaja. Sukladno pravilima potrošačkog insolvencijskog postupka, cilj je tog specifičnog izvanparničnog postupka poštenog potrošača osloboditi od obveza koje preostanu nakon unovčenja njegove imovine i raspodjele prikupljenih sredstava vjerovnicima (tzv. oslobođenje od preostalih obveza) (Bodul i Grbić, 2018.:65). Dakle, kod potrošačkog stečaja razlikujemo materijalnopravni cilj, koji se odnosi samo na potrošača i predstavlja upravo differntia specifica u odnosu na korporativni stečaj. Sam je postupak žuran/hitan, pa sud može donositi odluke i bez usmene rasprave, ex offo odlučivati o činjenicama koje su važne za postupak i radi toga izvoditi sve potrebne dokaze. Posebne insolvencijske odredbe pružaju potrošačima pravo na otpust dugova u više etapa. Prva je određena u pokušaju potrošača da postigne izvansudski sporazum o ispunjenju obveza sa svojim vjerovnicima (Bodul, 2018.:160). Pokušaj i ne postizanje izvansudskog sporazuma o reguliranju duga preduvjet je pokretanja sudskog stečajnog postupka. Novelom ZSP-a iz 2018. godine potrošač može, ali i ne mora pokrenuti izvansudski postupak. Dakle, revidiraju se pravila o nužnosti provođenja prethodnog postupka pred savjetovalištem radi sklapanja izvansudskog sporazuma između potrošača i vjerovnika. Slijedi ponovni pokušaj postizanja sporazuma o reguliranju duga u okviru sudskog stečajnog postupka, uz mogućnost nametanja rješenja od suda kroz tzv. pravila o zabrani opstrukcije. Ako u okviru prethodne etape postupka vjerovnici ne prihvate plan za reguliranje dugova dužnika, slijedi otvaranje postupka stečaja potrošača i likvidacija dužnikove zapljenive 
imovine u okviru sudskog postupka za koji vrijede pojednostavljena pravila te, ovisno o prijedlogu dužnika, oslobađanje od preostalih dugova tijekom razdoblja do pet godina (tzv. razdoblje dobrog vladanja). Međutim, u RH prezaduženost fizičkih osoba nad kojima se provodi ovrha na novčanim sredstvima već duže vrijeme predstavlja velik problem. Zbog blokade računa građanima je otežan normalan život jer primanja mogu ostvarivati samo putem tzv. zaštićenih računa, pa je zakonodavac 2018. godine implementirao novi institut, tzv. ,jednostavni postupak stečaja potrošača“, kojim se omogućava deblokada računa dijelu insolventnih građana koji su u tzv. „dugotrajnoj blokadi“ za relativno male iznose duga. $\mathrm{Uz}$ spomenute mjere, problem blokiranih računa građana paralelno se rješavalo i kroz novi Zakon o otpustu dugova fizičkih osoba te implementiranjem novog Zakona o provedbi ovrhe na novčanim sredstvima. U konačnici, iako primjena kako starog SZ-a tako i novog SZ-a u odnosu na dužnike pojedince još nije utvrdila odgovarajuće standarde za pojedine probleme te je većina odredbi u potpunosti ostala neiskušana u praksi, tek će primjena ZSP-a trebati iskristalizirati određena tumačenja, a jedno je od njih i problematika osiguranika prava na mirovinu, kao dužnika, u postupku potrošačkog stečaja.

\section{Osvrt na dosadašnju literatura i doprinos rada}

Provedbu kao i cilj potrošačkog stečajnog postupka detaljno uređuje ZSP, a pritom se na odgovarajući način primjenjuju odredbe SZ-a. U RH postoji stotinjak znanstvenih tekstova koji se bave opsežnom i složenom problematikom stečajne regulative, i to prvenstveno problematikom korporativnog stečaja. Postoji skroman broj i monografija iz područja stečaja, za razliku od kapitalnih djela i znanstvenih članaka koja postoje u SAD-u i njemačkom pravu. Ipak, posljednjih godina sve veći broj studija analizira ekonomske i pravne učinke likvidacijskih i reorganizacijskih stečajnih postupaka. No za ovaj su rad važniji tekstovi koji analiziraju institut potrošačkog stečaja, a čiji je broj puno skromniji.

Empirijski i literarno sustav mirovinskog osiguranja konceptualizira se u radovima profesora Potočnjaka i profesorice Vukorepe. Sa stajališta istraživanja, literatura manjeviše komunicira, u konsenzualnom smislu, o pozitivnim efektima, ali i o problemima funkcioniranja postojećeg sustava, o argumentima za i protiv transformacije postojećeg modela mirovinskog sustava, o traganju za univerzalnim modelom u okviru europske ekonomske integracije te o tendencijama konvergencija i divergencija mirovinskog sustava u kontekstu transformacije države blagostanja. Također, diskusije o diskriminaciji, kako se ona prepoznaje i dokazuje, prikazane su prvenstveno u knjigama, poglavljima i člancima prof. Potočnjaka i prof. Uzelca. Navedeni autori govoreći o važnosti shvaćanja antidiskriminacijskog zakonodavstva posebno ističu činjenicu kako naša sudska praksa mora prihvatiti činjenicu da se preko judikature ECHR-a i Suda pravde Europske unije afirmira princip precedenata, i time sudske prakse kao formalnog izvora prava.

Ipak, kako postupak potrošačkog stečaja utječe na položaj osiguranika prava na mirovinu ostalo je nerazjašnjeno u postojećoj literaturi. Iz rečenog uočavamo kako postoje- 
ća literatura ne pruža odgovor, kao ni korisna objašnjenja i primjerene pristupe vezano za položaj osiguranika prava na mirovinu u kontekstu postupka stečaja potrošača. Stoga će ovo istraživanje predstavljati prvu sustavnu i znanstveno utemeljenu analizu moguće reforme postojećeg postupka stečaja potrošača.

\section{Empirijski indikatori rasta umirovljeničke populacije u ukupnoj demografskoj populaciji: RH u kontekstu europskih kretanja}

RH je kao i cjelokupna Europska unija suočena s kontinuiranim starenjem stanovništva. Podaci iz tablice 1 pokazuju kako se od 2011. godine povećava udio osoba starijih od 65 godina u ukupnom stanovništvu. Prema posljednjim dostupnim podacima, 20,1\% ukupnog hrvatskog stanovništva čine osobe starije od 65 godina. Starenje stanovništva rezultira slabljenjem potrošačkoga i inovacijskoga kapaciteta te stvara dodatni pritisak na javne financije, posebno $s$ aspekta izdataka za mirovine i socijalnu zaštitu. RH u promatranom razdoblju održava relativno stalne izdatke za mirovine (5,5\% BDP-a u 2017.), dok je u slučaju izdataka za socijalnu zaštitu zabilježen trend smanjivanja u odnosu na 2016. godinu.

Tablica 1.

Pokazatelji stanovništva do 65 godina i starijih u RH u razdoblju 2009. - 2017. godine (2018.)

\begin{tabular}{|c|c|c|c|c|c|c|c|}
\hline 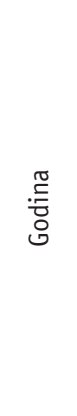 & 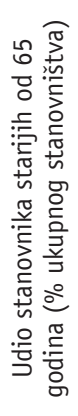 & 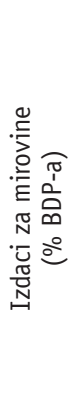 & 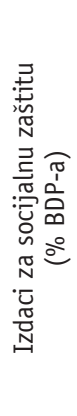 & 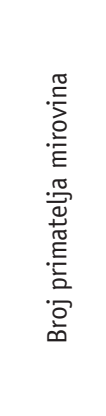 & 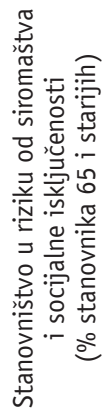 & 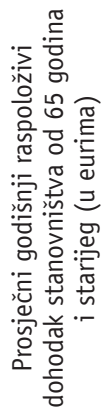 & 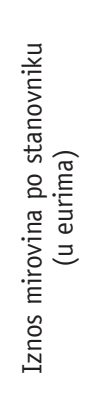 \\
\hline 2009. & 17,9 & 5,6 & 20,5 & 623.128 & n.a & n.a. & 598,74 \\
\hline 2010. & 17,8 & 5,6 & 20,8 & 623.893 & 37,5 & 4.814 & 590,30 \\
\hline 2011. & 17,7 & 5,5 & 20,6 & 623.683 & 36,4 & 4.692 & 578,19 \\
\hline 2012. & 17,9 & 5,5 & 21,2 & 624.412 & 33,1 & 4.657 & 558,38 \\
\hline 2013. & 18,1 & 5,6 & 21,0 & 623.626 & 31,9 & 4.573 & 562,38 \\
\hline 2014. & 18,4 & 5,7 & 21,4 & 634.883 & 29,7 & 4.720 & 577,20 \\
\hline 2015. & 18,8 & 5,5 & 21,4 & 642.646 & 31,8 & 4.768 & 576,08 \\
\hline 2016. & 19,2 & 5,5 & 20,9 & 650.781 & 32,8 & 4.963 & 610,00 \\
\hline 2017. & 19,6 & 5,5 & 20,5 & 656.501 & 32,7 & 5.285 & 627,02 \\
\hline 2018. & 20,1 & n.a & n.a & n.a & 32,0 & 5.574 & n.a \\
\hline
\end{tabular}

Izvor: Eurostat, 2019. 
Međutim, RH tijekom cijeloga promatranog razdoblja (osim u 2011.) bilježi stalno povećanje broja primatelja mirovina ${ }^{2}$, kojih je u 2017. godini bilo 656.501. Osobe starije od 65 godina, a koje zauzimaju najveći postotak u strukturi primatelja mirovina, najčešće su izložene najvećem riziku od siromaštva i socijalne isključenosti. O tome svjedoče i podaci, prema kojima je 32,0\% stanovnika RH starijih od 65 godina suočeno $s$ rizikom od siromaštva i socijalne isključenosti. Takva situacija proizlazi iz prosječne razine raspoloživoga godišnjega dohotka starijega stanovništva, a koja je u 2018. godini iznosila 5574 eura. Nadalje, iako podaci upućuju na povećanje prosječnog iznosa mirovina po stanovniku u zadnjih nekoliko godina, njihova je razina još uvijek niska, te je u 2017. godini iznosila 627,02 eura. Međutim, kako bi se dobio potpuni uvid u socijalnu i materijalnu situaciju starijega stanovništva u RH, potrebno je izvršiti usporedbu ključnih pokazatelja sa zemljama članicama EU-a (posebno onima s usporedivim karakteristikama). Navedeno je prikazano u tablici 2.

Tablica 2.

Pokazatelji stanovništva do 65 godina i starijih u EU-u u 2018. godine

\begin{tabular}{|c|c|c|c|c|c|}
\hline$\frac{\stackrel{\sigma}{\vec{E}}}{\stackrel{\stackrel{\vec{E}}{N}}{N}}$ & 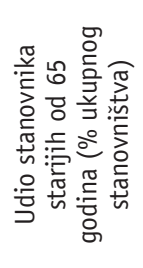 & 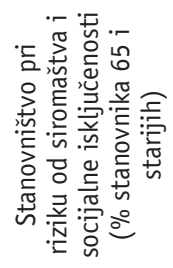 & 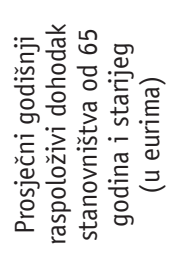 & 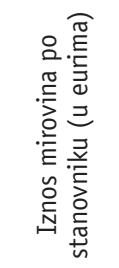 & 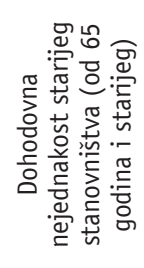 \\
\hline EU & 19,7 & 18,3 & 16.162 & $2.705,54$ & 4,17 \\
\hline Belgija & 18,7 & 17,6 & 19.220 & $3.046,68$ & 3,06 \\
\hline Bugarska & 21,0 & 45,1 & 2.860 & 415,23 & 4,82 \\
\hline Češka & 19,2 & 15,6 & 7.181 & $1.161,17$ & 2,5 \\
\hline Danska & 19,3 & 9,6 & 24.514 & $4.567,39$ & 3,20 \\
\hline Njemačka & 21,4 & 19,0 & 19.809 & $3.161,14$ & 4,29 \\
\hline Estonija & 19,6 & 47,4 & 6.527 & 688,39 & 3,64 \\
\hline Irska & 13,8 & 20,9 & 21.307 & $2.527,81$ & 3,73 \\
\hline Grčka & 21,8 & 21,3 & 7.913 & $2.294,89$ & 3,86 \\
\hline Španjolska & 19,2 & 17,6 & 14.240 & $1.871,56$ & 4,50 \\
\hline Francuska & 19,7 & 9,9 & 22.864 & $4.001,05$ & 4,10 \\
\hline RH & 20,1 & 32,0 & 5.574 & 627,02 & 4,76 \\
\hline Italija & 22,6 & 20,2 & 17.001 & $3.077,74$ & 4,86 \\
\hline
\end{tabular}

${ }^{2} \mathrm{U}$ analizu su uključene samo osobe od 65 godina i starije. 


\begin{tabular}{|c|c|c|c|c|c|}
\hline $\begin{array}{l}\stackrel{\widetilde{\sigma}}{\vec{E}} \\
\stackrel{\mathbb{N}}{N}\end{array}$ & 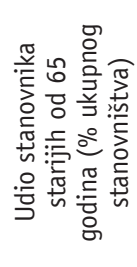 & 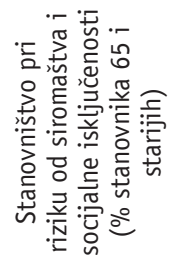 & 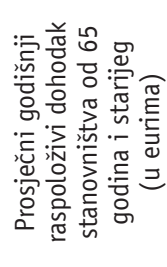 & 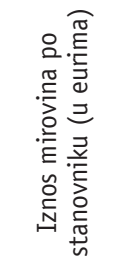 & 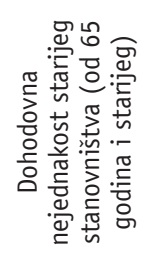 \\
\hline Cipar & 15,9 & 23,5 & 12.493 & $1.618,46$ & 4,55 \\
\hline Latvija & 20,1 & 49,0 & 4.669 & 762,66 & 5,1 \\
\hline Litva & 19,6 & 42,7 & 4.837 & 696,87 & 4,87 \\
\hline Luksemburg & 14,3 & 12,1 & 43.955 & $4.347,79$ & 4,98 \\
\hline Mađarska & 18,9 & 13,3 & 5.294 & 797,87 & 3,4 \\
\hline Malta & 18,8 & 26,7 & 11.259 & $1.241,86$ & 3,10 \\
\hline Nizozemska & 18,9 & 11,8 & 20.428 & $3.891,35$ & 3,02 \\
\hline Austrija & 18,7 & 14,5 & 24.297 & $3.990,64$ & 3,8 \\
\hline Poljska & 17,1 & 18,1 & 6.107 & 924,41 & 3,42 \\
\hline Portugal & 21,5 & 21,2 & 8.584 & $1.858,37$ & 5,23 \\
\hline Rumunjska & 18,2 & 32,8 & 3.058 & 591,18 & 4,5 \\
\hline Slovenija & 19,4 & 20,1 & 11.460 & $1.501,92$ & 3,4 \\
\hline Slovačka & 15,5 & 11,9 & 6.974 & 888,16 & 2,31 \\
\hline Finska & 21,4 & 14,0 & 20.986 & $3.913,23$ & 3,0 \\
\hline Švedska & 19,8 & 14,7 & 21.398 & $4.043,93$ & 3,43 \\
\hline Ujedinjeno Kraljevstvo & 18,2 & n.a. & n.a. & $3.208,72$ & n.a. \\
\hline
\end{tabular}

Izvor: Eurostat, 2019.

Podaci upućuju na to kako RH i u usporedbi s prosjekom EU-a ima relativno staro stanovništvo, pri čemu samo šest zemalja članica ima starije stanovništvo. Što se tiče stanovništva starijega od 65 godina koje se nalazi u riziku od siromaštva i socijalne isključenosti, RH ostvaruje razinu koja je gotovo dvostruko veća od prosjeka EU-a te neznatno niža od one u Rumunjskoj. Najveće vrijednosti stanovništva starijega od 65 godina koje se nalazi u riziku od siromaštva i socijalne isključenosti imaju Latvija, Estonija i Bugarska. S druge strane, od zemalja usporedivih značajki, najnižu razinu toga pokazatelja bilježe Slovačka, Mađarska i Češka.

Nadalje, usporedbom sa zemljama članicama EU-a još je očigledniji problem godišnjega raspoloživog dohotka starijega stanovništva u RH, čija je vrijednost od 5574 
eura više no dvostruko niža od prosjeka EU-a, čime se RH ponovno nalazi sa samom dnu, odmah iza Bugarske, Rumunjske te Latvije i Litve te Mađarske.

Ipak, pravo stanje starijega stanovništva dobije se uvidom u podatke o prosječnim iznosima mirovina. Sa sadašnjim iznosom od 627,02 eura, RH se nalazi iznad razina Bugarske i Rumunjske, dok sve ostale zemlje članice EU-a ostvaruju više razine. Nadalje, prosječna je razina mirovine u RH za više od četiri puta niža od prosjeka EU-a.

RH ostvaruje i jednu od najviših razina dohodovne nejednakosti starijega stanovništva, a koju je prema Eurostatu (2019.) moguće definirati kao „odnos ukupnoga dohotka $20 \%$ stanovništva sa najvišim primanjima i ukupnoga dohotka $20 \%$ stanovništva sa najnižim primanjima“. Prema tome pokazatelju „,vodeće“ mjesto među zemljama članicama EU-a zauzimaju Portugal, Luksemburg, Litva i Italija.

\section{Položaj starije populacije u postupku potrošačkog stečaja: poredbeno- pravna analiza}

Odgovor na pitanje rješavanja prezaduženosti starijih osoba te pronalaženja optimalnog modela postupka za njihovo oslobađanje od preostalih dugova nije jednostavan. Iako je potreba za izmjenom propisa o potrošačkom stečaju i prilagođavanju novim socioekonomskim uvjetima, pa i krizi mirovinskih sustava, sagledana odavno, a uzroci koji su to zahtijevali nisu došli naglo i neočekivano, u EU-u, kao i šire, cijeli proces $s$ institucionalnog aspekta teče dosta sporo. To je osobito točno ako se uzme u obzir činjenica da je „opći“ potrošački stečaj u europskom pravnom krugu prvotno uveden u Danskoj 9. svibnja 1984. godine (stupio na snagu 1. srpnja 1984.), kada je Stečajnom zakonu dodan IV. dio (Kilborn, 2009.:157; Laleta, 2017.).

RH je, uz Grčku, posljednja zemlja koja je implementirala potrošački stečaj. Štoviše, iako suočene $s$ istim problemima u području funkcionalizacije stečajno pravne zaštite potrošača te sličnim pravno-političkim zahtjevima, moderne su države krenule različitim putem pri formiranju i reformiranju instituta potrošačkog stečaja. Neke su od njih izvršile radikalnije promjene u samoj strukturi postupka, druge su bile umjerenije i nastojale što više zadržati kontinuitet tradicionalističkih koncepcija, dok treće još tragaju za konceptom koji će udovoljiti potrebama dužnika i vjerovnika, ali i tržišta. Štoviše, i pravni modeli potrošačkog stečaja koji su među sobom veoma slični, kao model Luksemburga, Nizozemske i Francuske, pokazuju znatne razlike oko središnjih pitanja. Ipak, pravna je teorija ukazala na nekoliko kriterija na osnovi kojih se može praviti razlika između tzv. liberalnih i tzv. konzervativnih modela potrošačkog stečaja (Bodul, 2011.:360 et seq; Bodul, 2017.:329 et seq). 


\subsection{Liberalni sustavi potrošačkog stečaja}

Liberalni sustavi potrošačkog stečaja propisuju manji broj preduvjeta za pokretanje postupka potrošačkog stečaja, što naravno rezultira velikim brojem takvih vrsta stečajeva. Naglasak je stavljen na pružanje nove šanse (engl. fresh start) za pojedinca potrošača, dakle u prvi se plan postavljaju interesi dužnika potrošača, što znači da se rizik prebacuje na vjerovnike kao ekonomski jaču stranu dvostranog pravnog odnosa. U takvoj zakonskoj regulaciji primjećujemo težnju prema ograničavanju prava vjerovnika u korist prava dužnika, što je i u skladu s idejom vodiljom postupka stečaja potrošača, ekonomskom rehabilitacijom dužnika, dok to nije slučaj kod stečaja pravnih osoba, u komu pretežu prava vjerovnika (Bodul, 2014.:330). Exempli gratia, brojne reforme potrošačkog zakonodavstva u francuskom pravu, počevši od rigidnog tzv. Loi Nertza do sada, kreirale su takva pravila o potrošačkom stečaju koja dopuštaju određenim skupinama automatski otpust dugova kako bi se izbjeglo nepotrebno gomilanje administrativnih troškova (Bodul i Grbić, 2017.:175). Uvođenjem postupka tzv. administriranja dugom, francuski je zakonodavac u početku dopuštao samo smanjenje kamatne stope i produženje rokova otplate duga, dok sam otpust dugova nije bio dopušten. No, takvo uređenje nije dalo značajnijih rezultata budući da su se dužnici nerijetko vraćali u postupak. Stoga se pokazala potreba za revidiranjem sustava administriranja dugom. Naime, francuski je zakonodavac još 1999. godine ovlastio tzv. Komisiju za donošenje izvanrednih mjera, kojima se plaćanje dugova odgađalo na rok od dvije godine. Ukoliko se u tom razdoblju financijsko stanje dužnika ne bi popravilo, dužnik je dobivao djelomičan otpust dugova. Maksimalno trajanje plana otplate duga ograničeno je izmjenama zakona iz 2003. godine na deset godina. Osnovna je ideja francuskog uređenja da dužnik i vjerovnik, uz suradnju Komisije, postignu sporazum o reguliranju duga. Štoviše, francuski zakonodavac ide tako daleko da ovlašćuje sud odnosno Komisiju da strankama „nametne“ sporazum ukoliko ga one same ne postignu. Ipak, praksa je pokazala da velik broj dužnika ne može isplatiti ni dio svojih dugova, zbog čega je zakonodavac bio prisiljen poduzeti i radikalnije mjere. $U$ tom je pravcu Komisija od 2004. godine ovlaštena da dužnike, čija je situacija određena kao „trajno narušena“, uputi u postupak osobnog oporavka (Kilborn, 2005.: 636.). Navedeni postupak sličan je stečajnom postupku koji je uređen odredbama Glave 7. američkog Stečajnog zakonika (Chapter 7 of Title 11 of the United States Code (Bankruptcy Code)) jer dopušta automatski otpust dugova u brzom postupku i bez obveze ispunjenja plana otplate duga. Naime, postupak se pokreće pred Komisijom, koja u roku od šest mjeseci mora utvrditi je li ispunjena pretpostavka trajno narušene ekonomske sposobnosti dužnika. U tom slučaju, predmet se upućuje sudu koji otvara postupak osobnog oporavka. Dužnost mu je da još jedanput prije pokretanja postupka ispita je li ekonomska sposobnost dužnika trajno narušena i pretpostavku njegove dobre vjere. Nakon toga imenuje se povjerenik, koji utvrđuje tražbine vjerovnika i priprema izjavu o dužnikovom financijskom stanju. Pod pretpostavkom da dužnik ima zapljenive imovine, ona mora biti prodana u roku od šest mjeseci. Ako se utvrdi da dužnik ne raspolaže nikakvom zapljenivom imovinom, postupak se završava i dužniku se ot- 
puštaju dugovi. Iako je, načelno, dopušteno taj postupak provesti neograničen broj puta, prijedlog za pokretanje postupka može se odbaciti polazeći od pretpostavke da višekratno ponavljanje ukazuje na izostanak pretpostavke dobre vjere kod potrošača. Statistički pokazatelji govore o velikoj zastupljenosti postupka osobnog oporavka. Štoviše, francuski je zakonodavac postupak potrošačkog stečaja učinio još učinkovitijim pravilima koja su imala za cilj smanjiti administrativni teret sudu. Naime, premda je početna ideja bila da postupak obuhvaća samo zapljenivu dužnikovu imovinu i njenu likvidaciju, a samo mali broj dužnika imao je zapljenivu imovinu, od 1. studenog 2010. godine Komisija ima ovlaštenje preporučiti postupak osobnog opravka bez likvidacije dužnikove imovine (Kilborn, 2005.: 636).

S druge strane, protok vremena od započinjanja reformi u SAD-u omogućava nam da analiziramo praktične implikacije njihovih reformi na srednji rok. Naime, pozitivno-pravna regulativa $\mathrm{SAD}$-a daje mogućnosti u okviru stečajnog postupka, s tim da je svaka oblikovana za drugu vrstu dužnika i ima predviđenu drugačiju proceduru. Predmetne opcije obuhvaćaju različite glave Stečajnog zakonika (Glavu 7., 9., 11., 12. i 13.), s tim da je Bankruptcy Abuse Prevention and Consumer Protection Act uveo dodatnu Glavu 15., koja obuhvaća postupke stečaja (potrošača) s međunarodnim elementom (Westbrook, 2005.). Dio Stečajnog zakonika, koji regulira stečaj potrošača, temelji se na ideji nove (financijske) prilike za potrošača. U prvi se plan postavljaju interesi dužnika, dok se rizik od nenamirenja prebacuje na vjerovnika kao ekonomski jaču stranu u dužničko-vjerovničkom odnosu.

Pravilima Glave 7. Stečajnog zakonika potrošačima koji udovoljavaju posebnim zahtjevima (tradicionalni model) omogućen je automatski otpust dugova, pa su, u korist vjerovnika, dužni likvidirati svoju zapljenivu imovinu. U većini slučajeva, međutim, stečajni upravitelj utvrđuje da dužnik ne raspolaže zapljenivom imovinom. Stoga dužnici, zapravo, dobivaju otpust duga nekoliko mjeseci od otvaranja stečajnog postupka bez obveze predaje ikakve imovine vjerovnicima. Pravna teorija ističe da je na taj način uređen potrošački stečaj kojim se na relativno lagan način dužnik (potrošač) oslobađa dugova ako pripada određenoj kategoriji, tj. ako je riječ o potrošaču niže platežne sposobnosti, što je rezultat značaja i uloge kreditnog tržišta u SAD-u (Bodul, 2017.).

Manji broj postupaka pokreće se u skladu s pravilima Glave 13. Stečajnog zakonika, a kojom je predviđen plan otplate duga u razdoblju od tri do pet godina. Dovršetkom plana otplate duga dužnik se oslobađa preostalih dugovanja (dužnik koji ne udovoljava tzv. testu podobnosti). Naime, na gospodarskom planu potiče se ozračje ulaska u kreditne odnose, a u slučaju nesposobnosti za plaćanje osigurava se brza reintegracija kroz institut potrošačkog stečaja, odnosno omogućava se brz povratak potrošača na kreditno tržište i ponovno zaduživanje. Ipak, ne mogu se zanemariti njegove druge bitne funkcije: osiguranje pravične raspodjele stečajne mase vjerovnicima, učinkovito administriranje stečajnom masom te odgovarajuće sankcije zbog zloupotreba potro- 
šačkog stečajnog postupka. Sprječavanje zlouporaba bio je i cilj reforme potrošačkog stečaja u SAD-u, koja je provedena 2005. godine stupanjem na snagu naprijed navedene BAPCA-e. Intencija je bila smanjiti broj dužnika koji su ovlašteni pokrenuti postupak primjenom pravila Glave 7. Stečajnog zakonika uvođenjem matematički formuliranog "testa podobnosti“ kao orijentira o platežnoj sposobnosti potrošača. Takvo uređenje trebalo je usmjeriti potrošače prema postupku koji uključuje plan otplate duga putem odredbi Glave 13. Stečajnog zakonika (Bodul, 2017.; Hallinan, 1986.:49; Howard, 1987.:1047; Jackson, 1985.:1393,1402; Tabb, 1990.:89-103).

Međutim, u praksi reformom nisu ostvareni željeni ciljevi. Razloge neuspjeha reforme pravna je teorija koncipirala kroz tri juristička i jedan kvazijuristički razlog. Tako se smatra da je uvođenje tzv. postupka prethodnog obveznog savjetovanja samo poskupilo i nepotrebno odužilo cijeli postupak otpusta dugova. Uvođenje testa podobnosti, koji je imao za cilj spriječiti zloporabe, proizvelo je suprotan učinak, budući da se pokazalo kako se pokretanje postupka prema pravilima Glave 7. Stečajnog zakonika de lege lata još više koristi, ali sada s uvećanim troškovima. Poseban je problem nejasna i nedovoljna nomotehnička preciznost zakonodavnog uređenja, što za posljedicu ima brojne postupke u kojima se nerijetko od Vrhovnog suda tražilo tumačenje značenja upotrijebljenog nazivlja. Posljednji razlog, koji nužno nije samo pravni, leži u činjenici što se prezaduženost potrošača često „podudara“, odnosno tražbine potječu s naslova zdravstvene zaštite do te mjere da je moguće tvrditi kako je osiguranje odgovarajuće medicinske zaštite i plaćanje te zaštite glavni razlog prezaduženosti potrošača, a time i pokretanja postupka potrošačkog stečaja. U SAD-u je napravljen prijedlog „Zakona o osobnom bankrotu uzrokovanog medicinskim dugovima" (Medical Bankruptcy Fairness $A c t)$, koji je trebao imati za cilj stvaranje posebne kategorije dužnika s medicinskim dugovima koji bi se mogli osloboditi od preostalih dugova. Navedeni zakonski prijedlog nije prošao zakonodavnu proceduru u američkom Kongresu, no svejedno je ponudio izuzetno zanimljiva rješenja, koja će svakako biti i predmet budućih znanstvenih istraživanja (Ruijter, 2008.:87; Pottow, 2008.:349-405; Dranove 2006.:7483; Radović, 2006.).

Iako je njihov mirovinski sustav temeljen na obveznim individualnim računima zasnovanim na punoj kapitalizaciji, većina je mirovinskih računa pravilima o izuzimanju izuzeta u slučaju otvaranja potrošačkog stečaja. Međutim, iako je američki Stečajni zakonik federalnog karaktera, svaka savezna država ima specifična pravila o izuzimanju, pa nisu sva sredstva u fondu za umirovljenje zaštićena stečajnim propisima. To je posebno bitno jer izvješće iz 2018. godine pokazuje kako jedna od sedam osoba koje podnesu zahtjev u SAD-u ima 65 i više godina, što je gotovo petostruko povećanje u odnosu na zadnjih 25 godina. Studija pokazuje da je takav trend nuspojava nekoliko sudarajućih društvenih i ekonomskih tendencija u SAD-u, što je rezultat činjenice da umirovljenici žive duže, plaćaju sve veće medicinske troškove za privilegiju da ostanu živi, dok mnogi od njih imaju malu ili nikakvu mirovinu i skromnu osobnu ušteđe- 
vinu. Štoviše, i druge relevantne empirijske studije pokazuju kako postoji korelacija, odnosno signifikantna uzročno posljedična veza između modela potrošačkog stečaja i dobne granice potrošača (Thorne i sur., 2018.).

\subsection{Konzervativni sustavi potrošačkog stečaja}

S druge su strane konzervativni sustavi potrošačkog stečaja. Oni su opterećeni velikim brojem preduvjeta, što pretpostavlja vođenje manjeg broja, nerijetko neučinkovitih, stečajnih postupaka nad imovinom potrošača. Glavni razlog neučinkovitosti takvih postupaka postavljanje je ispunjenja obveza dužnika kao primarnog cilja potrošačkog stečaja. Stoga se i instituti oslobođenja od preostalih dugova drugačije reguliraju propisujući duge i obvezne planove otplate duga, čije je ispunjenje preduvjet okončanja postupka potrošačkog stečaja (Bodul, 2014.:335). Exempli gratia, njemački model potrošačkog stečaja čini više etapa. Prva je obveza dužnika da s vjerovnikom izvansudskim putem pokuša zaključiti sporazum o reguliranju duga. U tom je pravcu dužnik obvezan ishoditi potvrdu osobe koja provodi izvansudski sporazum, odnosno agencije, a iz koje treba biti vidljivo da je dužnik prethodno pokušao izvansudskim putem regulirati dug najmanje šest mjeseci prije pokretanja sudskog postupka. Ne uspije li izvansudski postupak postizanja sporazumna o reguliranju duga, postupak se nastavlja pred sudom, i to svojevrsnom sudskom medijacijom tako da sud ima ovlaštenja „nadomjestiti“ izostanak suglasnosti manjine vjerovnika. Ta, u biti prva, faza sudskog postupka može biti okončana zaključenjem sporazuma, ali se može dogoditi da do zaključenja sporazuma ne dođe. U tom slučaju slijedi likvidacija dužnikove zapljenive imovine. Kao poseban problem u toj fazi postupka u pravnoj se teoriji ističe to što dužnici imaju vrlo malo ili uopće nemaju zapljenive imovine kojom bi se mogle namiriti tražbine vjerovnika. Dužnik potrošač dužan je izjasniti se, pri podnošenju prijedloga za otvaranje insolvencijskog postupka, želi li se koristiti institutom oslobađanja od preostalih dugova. Ukoliko potrošač izjavi da se želi koristiti navedenim institutom, a pod pretpostavkom da vjerovnici ne istaknu razloge zbog kojih bi se dužniku moglo uskratiti pravo na korišstenje instituta oslobađanja od preostalih dugova, sud najavljuje oslobođenje od preostalih dugova. Navedeno razdoblje od šest godina uvedeno je reformom insolvencijskog zakonodavstva 2001. godine, do kada se predviđalo da to razdoblje traje sedam godina. Međutim, kako je razdoblje tzv. dobrog vladanja u suštini samo jedna od faza potrošačkog stečaja, kojoj prethodi najprije izvansudsko, a onda sudsko postizanje sporazuma o reguliranu dugova, u praksi se pokazalo da se na otpust dugova treba čekati gotovo 11 godina, pa i više. Nadalje, u praksi se učestalost vršenja isplata planom otplate duga pokazala upitnom, budući da se u velikom broju slučajeva za vjerovnike ne ostvaruje ekonomska korist. Zbog navedenoga u pravnoj teoriji sve su izraženija razmišljanja prema kojima postoji potreba nužnih promjena uređenja potrošačkog stečaja, a posebice opravdani razlozi ishođenja bržeg otpusta dugova na način kako je to uređeno, primjerice, u francuskom pravu. Pokazalo se, naime, da većina potrošača nije u mogućnosti namiriti ni dio dugovanja, pa se u pitanje dovodi 
i sam ratio šestogodišnjeg razdoblja, a treba imati u vidu još i činjenicu kako je većina potrošača „na rubu egzistencije“ tijekom razdoblja otplate duga (Bodul i Žiković, 2014.:395) (Garašić, 2011.:1487-1514) (Kilborn, 2004.). Pravna se doktrina odredila i spram „života u insolvencijskom režimu“ i opravdano upozorila da to za posljedicu ima smanjenje društvenih kontakata i socijalno isključenje, a nerijetko potrošač živi na granici siromaštva. Smanjen je i pristup najosnovnijim uslugama te tržištu kapitala. U tom pravcu može se zaključiti da navedeni sustav uređenja instituta potrošačkog stečaja nameće dužnicima vrlo dugo razdoblje otplate duga, visoke i nepovratne troškove administriranja lokalne samouprave, a najčešće se njime ne ostvaruje namirenje vjerovnika (Backert i sur., 2009.: 285; Heuer, 2020.; Radović, 2006.).

\section{Položaj umirovljenika u hrvatskom postupku stečaja potrošača}

\subsection{Opće naznake}

Za razmatranje predmetne teme iznimno je bitno u kakvom su odnosu domaći pravni propisi koji uređuju različita prava starijih osoba s Ovršnim zakonom i Zakonom o stečaju potrošača. $S$ obzirom na ovršno načelo „brži u vremenu, jači u pravu”, javlja se mogućnost da se „brži“ vjerovnik u potpunosti namiri iz imovine dužnika, i to na način da nakon njegovog namirenja ne ostane neizuzetih sredstava za namirenje ostalih vjerovnika koji su podnijeli prijedlog kasnije. Stoga potrošački stečaj polazi od načelne pretpostavke ravnopravnosti vjerovnika (koja je relativizirana postojanjem stečajnih isplatnih redova, iako je u okviru istog reda osigurana ravnopravnost). Cilj potrošačkog stečaja, koji je procesno-pravnog karaktera i koji se vezuje isključivo za prava vjerovnika, ravnomjerno je i pravično namirenje prvenstveno hirografernih vjerovnika. Ipak, kada govorimo o pravima vjerovnika i dužnika u potrošačkom stečajnom postupku, primjećujemo težnju prema ograničavanju prava vjerovnika u korist prava dužnika, što je i u skladu s idejom vodiljom tog postupka, „rehabilitacijom“ dužnika (tzv. fresh-earned start). S druge strane, današnji mirovinski sustavi teže ostvarenju dvaju ciljeva: smanjenju siromaštva u starosti te održanju prihoda i životnog standarda u starosti na razini koja je slična onoj koju je pojedinac ostvarivao. Pravno-ekonomska teorija smatra mirovinski sustav adekvatnim ako uspijeva ispuniti oba cilja (Alessina, 2001.; Grott, 2004.).

Ipak, ocjena o ugroženosti jednog većeg broja starih osoba govori o generalnom izostanku sustavnog pristupa uređenju prava starijih osoba. Dakle, cilj je ukazati na specifični aspekt međusobne neusklađenosti određenih načela pa i odredbi ZSP-a s korpusom prava koji predstavljaju osnovu za zaštitu i promociju prava starijih osoba. Analizom tih dviju komplementarnih tema, koje smo tijekom argumentacije povezali u jedinstvenu cjelinu, treba prvenstveno krenuti od definicija potrošača u ZSP-u. Naime, potrošačem se u smislu ZSP-a smatra svaka fizička osoba koja sklapa pravni posao ili djeluje na tržištu izvan svoje trgovačke, poslovne, obrtničke ili profesionalne djelat- 
nosti. Potrošačem se smatra i fizička osoba obveznik poreza na dohodak od samostalne djelatnosti prema odredbama Zakona o porezu na dohodak i fizička osoba obveznik poreza na dobit prema odredbama Zakona o porezu na dobit ako: 1) nema više od 20 vjerovnika, 2) obveze iz obavljanja djelatnosti ne prelaze iznos od 100.000,00 kuna, 3) nema obveza iz radnih odnosa koje proizlaze iz obavljanja djelatnosti i 4) nije pokrenut predstečajni ili stečajni postupak. Dakle, vidimo kako sustav potrošačkog stečaja ne uzima u obzir različite okolnosti u kojima se nalaze različite „kategorije“ dužnika, ne priznajući tako da postoje dužnici koji ne mogu platiti dospjele obveze, ali imaju dodatne i stalne prihode kojima bi mogli vršiti redovite isplate dospjelih dugova vjerovnicima putem plana otplate duga, pritom zadržavajući minimalni životni standard. Ne priznaje, također, da postoje i dužnici koji imaju imovinu i prihode ispod minimalnog standarda, što ih čini nesposobnima za urednu isplatu vjerovnicima putem plana otplate duga. Nadalje, ne priznaje da postoje tzv. „povremeni dužnici bez imovine i prihoda", koje je trenutni gubitak posla ili pad u primanjima svrstao u krug osoba koje imaju imovinu ispod prosječnog standarda te da takvi povremeni dužnici bez imovine i prihoda pokazuju mogućnost da će u bližoj budućnosti moći vršiti djelomične i redovite uplate vjerovnicima putem plana otplate duga. Nadalje, ne priznaje da postoje i dužnici koji imaju imovinu kojom bi mogli isplatiti svoje vjerovnike, ali ne žele, te da bi takvoj kategoriji dužnika trebalo onemogućiti pristup potrošačkom stečaju, budući da je nad njima moguće provesti ovršni postupak. Dakle, kako kroz odredbe ZSP-a nije eksplicitno regulirana zaštita prava starih ljudi, ali je regulirana pozitivna obveza zaštite svih prava, vidljivo je kako osobe treće dobi nemaju poseban procesno pravni položaj u postupku. Štoviše, kako se na praktičnoj i empirijskoj razini pravo na mirovinu implicira samo kao pravo nezavisno od visine mirovine, pitanje je je li za najugroženije potrošače, kao što su nerijetko umirovljenici od kojih je veliki postotak znatno financijski onesposobljen, opravdano zakonsko rješenje prema kojem se potrošaču koji nema imovine ili je ona neznatne vrijednosti određuje razdoblje provjere ponašanja od pet godina.

\subsection{Jesu li starije osobe diskriminirane u hrvatskom postupku stečaja potrošača?}

Dosadašnja kako normativna tako i statističko deskriptivna analiza utvrđivanja činjenica pokazuje kako su umirovljenici, nezavisno od statusa u mirovinskom sustavu, jače pogođeni siromaštvom od ostatka populacije, odnosno da su im mirovine statistički značajno niže od prosjeka primanja ostatka populacije, što ih čini ranjivom kategorijom. Cilj je, dakle, pokazati kako odredbe ZSP-a u takvom slučaju izazivaju i pravne i faktične smetnje za adekvatno provođenje postupka stečaja potrošača, onemogućujući cilj samog postupka, odnosno ekonomsko-financijsko ozdravljenje subjekta. Kako se RH nizom akata obvezala svakome osigurati svaku potrebnu zaštitu u slučaju diskriminacije, „testom diskriminacije“ (Omejec, 2009.:958-960) analizirat ćemo praksu ECHR-a u postupcima po čl. 14. Europske konvencije (Zabrana diskriminacije) kako bismo utvrdili diskriminira li se u procesnom smislu umirovljenik u postupku stečaja 
potrošača. Namjera je da se razjašnjavanjem pravnih instituta koji su nastali kao rezultat dugogodišnje prakse i sagledavanjem njihovog međusobnog odnosa dođe do saznanja o pravno-logičkom mehanizmu odlučivanja ECHR-a te uvidi predstavlja li položaj umirovljenika u postupku stečaja potrošača diskriminaciju.

\section{1) Pripada li prigovor diskriminacije u područje zaštićenog prava ratione materiae?}

Prigovor diskriminacije svakako potpada pod područje zaštićenog prava ratione materiae Europske konvencije i u uskoj je vezi s praksom uz čl. 8. Konvencije. Za potrebe ovog rada bitna je veza čl. 8. i čl. 14. Europske konvencije. Iako ECHR nije dao iscrpnu definiciju prava na privatan život koje se jamči čl. 8., utvrdio je da je tu riječ o široko definiranom pojmu. Tako privatan život, između ostalog, uključuje i fizički i psihički integritet osobe, ugled i čast pojedinca te aktivnosti profesionalne i poslovne prirode, kao i ograničenje pristupa pojedinim profesijama ili zaposlenju (Omejec, 2013.: 931-932). Također, čl. 8. štiti pravo na identitet i osobni razvoj te pravo na uspostavljanje i razvijanje veza s drugim osobama i vanjskim svijetom (Gomien, 2007.:133). U navedenom kontekstu očigledna složenost društva u kojem je sve veći broj starijeg stanovništva, od kojih je velik postotak znatno onesposobljen fizički ili mentalno, predstavlja osnovu za opredjeljenje da se u sklopu čl. 14 i čl. 8. Konvencije govori posebno o zaštiti i promociji prava starijih osoba dajući im sigurnost da će se s njima postupati bez diskriminacije po osnovi životne dobi. Razlog je tomu i praksa gdje mnogi domaći zakoni samo nabrajaju osnovna ljudska prava starijih ljudi, dok je na empirijskoj i praktičnoj razini zaštita prava starijih osoba često samo hipotetička ili iluzorna.

2) Je li je povrijeđen članak Konvencije koji sadrži neko materijalno pravo?

U velikom broju predmeta praksa ECHR-a bila je najprije odrediti je li povrijeđena neka od materijalnih odredbi Konvencije, a onda je li time došlo i do diskriminacije. Najčešće, ako je utvrđena povreda materijalne odredbe, ECHR neće zasebno ispitivati povredu čl. 14. Takva se praksa ne temelji na logičkim posljedicama, već je dokaz određene sudske ekonomije. ${ }^{3}$ Međutim, u judikaturi ECHR-a ima predmeta, kao u konkretnom slučaju, u kojima je bilo teže utvrditi radi li se o povredi materijalne odredbe Konvencije ili o diskriminaciji. ${ }^{4}$ Tako je ECHR ispitivao i zahtjeve u kojima se samo pozivalo na povredu čl. 14. (Reid, 2012.:371-372).

\section{3) Postoji li razlika u postupanju?}

Nesporno je da će svako nepovoljno postupanje prema osobi koja spada u neku stariju dobnu skupinu, a koje je uvjetovano njenom dobi, predstavljati zabranjenu dobnu

\footnotetext{
3 Vidi Moustaquim protiv Belgije, presuda, 18. veljače 1991., br. 12313/86 te Smith i Grady protiv Ujedinjenog Kraljevstva, presuda, 27. rujna 1999., br. 33985/96, 33986/96.

${ }^{4}$ Hoffman protiv Austrije, presuda, 23. lipnja 1993., br. 12875/87 i Stubbings protiv Ujedinjenog Kraljevstva, presuda, 22. listopada 1996., br. 22083/93, 22095/93.
} 
diskriminaciju. Ipak, ovdje se ne radi o različitom postupanju prema osobama u sličnoj situaciji, već o istom postupanju s osobama u različitoj situaciji. Drugim riječima, ovdje neutralno pravilo ili praksa uskraćuje odnosno otežava pristup postupku potrošačkog stečaja većem broju pripadnika jedne društvene skupine, konkretno osobama starije dobi, u usporedbi s određenim brojem pripadnika „suprotne“ društvene skupine (primjerice osobama mlađim od 45 godina). Prikazani statistički podaci obuhvaćaju dovoljan broj pojedinaca, ukazujući na to da se ne radi o slučajnoj ili kratkoročnoj pojavi. Pri tomu je bitno naglasiti kako je namjera nepovoljnog postupanja nevažna, pa će odluka biti diskriminatorna bez obzira na to je li zakonodavac osobu namjeravao dovesti u nepovoljniji položaj.

4) Razlike u postupanju mogu se opravdati jedino ostvarenjem legitimnog cilja. Veza između ostvarenja legitimnog cilja i različitog postupanja mora biti opravdana. Uz to, za opravdanje različitog postupanja bitno je i načelo razmjernosti. Odnosno, mora postojati razmjernost korištenih sredstava i cilja kojem se teži. Ako je podnositelj stavljen u položaj koji je pretjerano nepovoljan za njega, a samo zbog ostvarenja tog cilja i time on trpi prekomjerni teret, doći će do diskriminacije. Konkretno, ono što se postavlja kao pitanje u našem je slučaju je li ostvarena pravedna ravnoteža između prava umirovljenika na pokretanje postupka stečaja potrošača i zahtjeva zaštite temeljnih prava ostalih pojedinca, odnosno je li zakonodavac dokazao da nije očigledno nerazumno očekivati da će se implementacijom unificiranog modela postupka stečaja potrošača ostvariti društveni cilj koji bi trebao biti koristan za društvo u cjelini. Naime, činjenica je da država u konkretnom slučaju nije objektivizirala kriterij treće dobi u postupku stečaja potrošača, čime nije spriječila postupanje kojim se određena osoba može dovesti u nepovoljni položaj zbog svoje dobne karakteristike. To onda dovodi do povrede prava na privatni život iz čl. 8. kao i povrede čl. 14. Europske konvencije. Dakle, ako se jednakost svodi na istovjetnost u postupanju, načelo zakonitosti nalaže podrobnije definiranje karakteristike potrošača jer bi se na taj način mogla primijeniti jednaka mjerila na nejednake situacije.

5) Premašuje li razlika u postupanju nacionalno područje slobodne prosudbe države? Opseg stupnja slobodne procjene varirat će u skladu s okolnostima, predmetom i njegovom pozadinom. $U$ tom smislu jedan od relevantnih čimbenika može biti postojanje ili nepostojanje zajedničkog temelja između država ugovornica. Ovdje je kompleksno utvrditi s nekakvom većom sigurnošću regulira li se u europskim sustavima potrošačkog stečaja položaj umirovljenika, i to ponajprije zbog raznih drugih modela socijalnih prestacija, pa je u sofisticiranoj analizi potrebno isključiti te druge utjecaje. Ipak, važno je istaknuti kako je problem umirovljenika u svim europskim zakonodavstvima ostavljen u velikoj mjeri neuređen, pa i znanstvena i stručna istraživanja u tom području nisu uznapredovala. 


\section{Zaključne preporuke}

Polazeći od teze da je jedna od socijalnih funkcija države osigurati minimalni iznos „za stare dane“ i da je neophodno da država putem instituta stečaja potrošača umanji opasnost i rizik od siromaštva u starosti, pitanje položaja umirovljenika u postupku stečaja potrošača postaje sve aktualnije. Štoviše, čini se da ga treba ozbiljno razmotriti upravo danas, kada se mnoge zemlje, uključujući i RH, nalaze pred krizom modela mirovinskih sustava. Stoga analiza značaja, ali i krize sadašnje socijalne države mora biti povezana s razmatranjem korelacije položaja umirovljenika i instituta potrošačkog stečaja, gdje se izoštrio problem koji u prvi mah nije bio dovoljno vidljiv ili je bio dobro prikriven. To više sada, u vrijeme učestalih financijskih kriza, pa i zdravstvene krize, kada izdvajanje nedovoljnih sredstava za mirovine izlaže stariju populaciju riziku da potencijalno postane nova ugrožena skupina koja će biti prisiljena ulaziti u razne oblike zaduženja, a posljedično i u potrošački stečaj.

Usporedbom angloameričkog i europskog modela otpusta dugova za potrošače mogu se uočiti neke temeljne razlike. Europska zakonodavstva relativno su kasno, prije 30-ak godina, uvela u pozitivno pravo institut oslobađanja potrošača od preostalih dugova. U većini slučajeva od dužnika se zahtijevalo ispunjenje obveznog plana otplate duga prije dobivanja oslobađanja od preostalih dugova. Nisu postojale nikakve odredbe o automatskom, brzom otpustu dugova budući da funkcija plana otplate duga nije bila samo ekonomska, već i moralna kategorija. Naime, mogućnost potrošačkog stečaja nije smjela predstavljati „lagan izlaz“ za potrošača. Razlika je postojala i u tomu što su europski zakonodavci naglasak stavljali na izvansudski model kojemu je cilj, primarno, ekonomska rehabilitacija, edukacija i, naravno, isplata duga. Ipak, postupno, zbog znatno izmijenjenih ekonomskih pretpostavki te čestih financijskih dvojbi, u novije vrijeme pokazala se potreba za radikalnijom intervencijom u potrošačku stečajnu regulativu. To rezultira reformama postupaka oslobađanja od preostalih dugova potrošača. Iako je dugoročne posljedice reformi potrošačkog stečaja u EU-u još uvijek moguće samo pretpostaviti, treba naglasiti kako je tendencija da se nacionalna zakonodavstva država članica EU-a sve više opredjeljuju za uređenje koje je okrenuto prema potrošaču i njegovim mogućnostima za novi, nerijetko brzi (zarađeni/financijski) početak (Kilborn, 2011.; Kilborn, 2007.; Ramsay, 1997.; Ramsay, 2020.).

U konačnici, može se zaključiti da su rezultat mnogobrojna stajališta i nerijetko otežana mogućnost izrade i formuliranja učinkovitog modela postupka potrošačkog stečaja. Iako sve zemlje za opći i identičan cilj imaju modernizaciju svoga prava, svaka ima svoju tradiciju, probleme i uvjete, pa stoje pred individualnim izazovima. Ipak, različita iskustva i uređenja koja su analizirana u ovom radu pokazuju da je među važnijim pitanjima o kojima će hrvatski zakonodavac pri reformi regulative trebati voditi računa pitanje tko su subjekti potrošačkog stečaja, pa i u tom kontekstu urediti poseban položaj umirovljenika u stečaju. 


\section{Literatura}

1. Alessina A.; Glaeser E. and Sacerdote B. (2001). Why Doesn't The US Have A European-Style Welfare State?. Harvard Institute of Economic Research, Discussion Paper Number 1933.

2. Backert, W.; Gechner, G.; Maischatz, K.; Brock, D. (2009). Consumer Bankruptcy in Germany, in: Niemi, J.; Ramsay, I. and Whitford, W. (Eds.). Consumer Credit, Debt and Bankruptcy. Hart Pub, 285.

3. Bankruptcy Abuse Prevention and Consumer Protection Act of 2005., Pub. L. No. 109-8.

4. Europska konvencija za zaštitu ljudskih prava i temeljnih sloboda, Narodne novine - Međunarodni ugovori, br. 18/97, 6/99, 14/02, 13/03, 9/05, 1/06, 2/10.

5. Bodul, D. (2011). Osobni stečaj: globalni trend i hrvatska perspektiva. Zbornik Pravnog fakulteta Sveučilišta u Rijeci, 32 (1): 351-377.

6. Bodul, D. (2017). O potrebi i mogućnosti implementacije instituta potrošačkog stečaja u pravni poredak Bosne i Hercegovine. ANALI Pravnog fakulteta Univerziteta u Zenici, 7 (14): 327-371.

7. Bodul, D. (2018). Dvije godine primjene Zakona o stečaju potrošača: parturient montes, nascetur ridiculus mus. Zbornik radova Pravnog fakulteta u Nišu, LVII (81): 151-171.

8. Bodul, D. i Grbić, S. (2017). Kratka prolegomena „o pravu na dom“ u Zakonu o stečaju potrošača. Revija za socijalnu politiku, 25 (2): 169-189.

9. Bodul, D. i Grbić, S. (2018). Zašto je važno analizirati praksu Europskog suda za ljudska prava: exemplar. HARMONIUS - Journal of Legal and Social studies in South East Europe, Dosije studio. Beograd. 63-87.

10. Bodul, D. and Tomas Žiković, I. (2014). Advantages and disadvantages of German consumer bankruptcy model: Guidelines for Croatian lawmaker. Ekonomski Vjesnik / Econviews: Review of contemporary business, entrepreneurship and economic issues, XXVII (2): 393-406.

11. Dranove D. (2006). Millenson ML. Medical bankruptcy: myth versus fact. Health Affairs, 25 (2): 74-83.

12. Eurostat (1) (2019). https://ec.europa.eu/eurostat/tgm/table.do?tab=table\&init $\equiv 1$ \&language $=$ en \&pcode $=$ tps00028\&plugin $=1$. (Pregledano 10.11.2020.)

13. Eurostat (2) (2019). http://appsso.eurostat.ec.europa.eu/nui/show.do?dataset=ilc peps01\&lang=en. (Pregledano 10.11.2020.)

14. Eurostat (3) (2019). https://ec.europa.eu/eurostat/tgm/table.do?tab=table\&init $=1$ \&language $=$ en $\&$ pcode $=$ tps00103\&plugin $=1$. (Pregledano 10.11.2020.)

15. Eurostat (4) (2019). https://ec.europa.eu/eurostat/tgm/table.do?tab=table\&init $=1$ \&language $=$ en \&pcode $=t p s 00098 \&$ plugin $=1$. (Pregledano 10.11.2020.)

16. Eurostat (5) (2019). https://appsso.eurostat.ec.europa.eu/nui/show.do?dataset=spr pns ben\&lang=en. (Pregledano 10.11.2020.)

17. Eurostat (6) (2019). https://ec.europa.eu/eurostat/web/gdp-and-beyond/quality-of-life/data. (Pregledano 10.11.2020.) 
18. Eurostat (7) (2019). https://appsso.eurostat.ec.europa.eu/nui/show.do?dataset=spr exp pens\&lang=en. (Pregledano 10.11.2020.)

19. Eurostat (8) (2019). https://ec.europa.eu/eurostat/tgm/table.do?tab=table\&init $=1$ \&language $=$ en\&pcode=tespn080\&plugin $=1$. (Pregledano 10.11.2020.)

20. Garašić, J. (2011). Kako zakonski regulirati “osobni stečaj” u Hrvatskoj. Zbornik Pravnog fakulteta u Zagrebu, 61 (5): 1487-1514.

21. Gomien, D. (2007). Europska konvencija o ljudskim pravima. Zadar: Naklada d.o.o. - Pravni fakultet Sveučilišta u Rijeci. 133.

22. Grott H.; Tang P. and Nahuis R. (2004). Is the American Model Miss World? Choosing between the Anglo-Saxon model and a Europena-style alternative. Tjalling C. Koopmans Research Institute Discussion Paper Series nr: 04-26.

23. Hallinan, C. G. (1986). The "Fresh Start" Policy in Consumer Bankruptcy: A Historical Inventory and an Interpretative Theory. University of Richmond. Law Review, 21 (1): 49.

24. Heuer, J. O. (2020). Hurdles to debt relief for "no income no assets" debtors in Germany: A case study of failed consumer bankruptcy law reforms. International Insolvency Review, 29 (S1).

25. Hoffman protiv Austrije, presuda, 23. lipnja 1993., br. 12875/87.

26. Howard, M. (1987). A Theory of Discharge in Consumer Bankruptcy. Ohio State Law Journal, 48 (1): 1047.

27. Jackson, T. H. (1985). The Fresh-Start Policy in Bankruptcy Law. Harvard Law Review, 98 (1): 1393-1402.

28. Kilborn, J. J. (2004). The Innovative German Approach to Consumer Debt Relief: Revolutionary Changes in German Law, and Surprising Lessons for the United States. Northwestern Journal of International Law \& Business, 24 (1): 257.

29. Kilborn, J. J. (2005). La responsabilisation del'economie: What the United States can learn from the new french law on consumer overindebtedness. Michigan Journal of International Law, 26: 636.

30. Kilborn, J. J. (2009). Twenty-Five Years of Consumer Bankruptcy in Continental Europe: Internalizing Negative Externalities and Humanizing Justice in Denmark. International Insolvency Review, 18 (1): 155.

31. Kilborn, J. J. (2011). Expert Recommendations and the Evolution of European Best Practices for the Treatment of Overindebtedness, 1984-2010, in: Deventer: Kluwer, Sebastian Kortmann and Dennis Faber, (Eds.). Law of Business and Finance, 11 (1): 13.

32. Laleta, S. (2017.). Restructuring of Companies and Employment Security. Economic and Social Development - 22nd International Scientific Conference on Economic and Social Development - "The Legal Challenges of Modern World", 22 (1): 179-189.

33. Moustaquim protiv Belgije, presuda, 18. veljače 1991., br. 12313/86

34. Omejec, J. (2009). Zabrana diskriminacije u praksi Europskog suda za ljudska prava. Zbornik Pravnog fakulteta u Zagrebu, 59 (5): 958-960. 
35. Omejec, J. (2013). Konvencija za zaštitu ljudskih prava i temeljnih sloboda u praksi Europskog suda za ljudska prava. Strasbourški acquis. Zagreb: Novi informator. 931-932.

36. Pottow, J. (2008). Did Bankruptcy Reform Fail? An Empirical Study of Consumer Debtors. R. M. Lawless et al., co-authors. American Bankruptcy Law Journal, 82 (3): 349-405.

37. Radović, V. (2006.) Individualni stečaj: stečaj nad imovinom fizičkog lica. Beograd: Dosje.

38. Ramsay, I. (1997). Models of Consumer Bankruptcy: Implications for Research and Policy. Journal of Consumer Policy, 20: 269-287.

39. Ramsay, I. (2020). The new poor person's bankruptcy: Comparative perspectives. International Insolvency Review, 29 (S1).

40. Reid, K. (2012). A practitioner's guide to the European Convention on Human Rights. London: Sweet \& Maxwell, Thomson Reuters. 371-372.

41. Ruijter, A. (2008). The Business of Health Care in the United States: What is wrong with the Standard of Economic Efficiency?. Loyola Journal of Public Interest Law. 10 (1): 87.

42. Smith i Grady protiv Ujedinjenog Kraljevstva, presuda, 27. rujna 1999., br. 33985/96, 33986/96.

43. Stečajni zakon, Narodne novine, 44/96, 161/98, 29/99, 129/00, 123/03, 197/03, 187/04, 82/06, 116/10, 25/12, 133/12 i 45/13.

44. Stečajni zakon, Narodne novine, 71/15, 104/17.

45. Stubbings protiv Ujedinjenog Kraljevstva, presuda, 22. listopada 1996., br. 22083/93, 22095/93.

46. Tabb, C. J. (1990). The Scope of the Fresh Start in Bankruptcy: Collateral Conversions and the Discharge-ability Debate. George Washington Law Review, 59 (1): 56, 89-103.

47. Westbrook, J. L. (2005). Chapter 15 at Last. American Bankruptcy Law Journal, 79: 713-728.

48. Zakon o mirovinskom osiguranju, Narodne novine, br. 157/13, 151/14, 33/15, 93/15 i 120/16, 18/18, 62/18, 115/18 i 102/19.

49. Zakon o otpustu dugova fizičkih osoba, Narodne novine, br. 62/18.

50. Zakon o provedbi ovrhe na novčanim sredstvima, Narodne novine, br. 68/18, $02 / 20,46 / 20,47 / 20$.

51. Zakon o stečaju potrošača, Narodne novine, br. 100/15. i 67/18. 


\title{
On the Future of Pensioners in Post-Pandemic Croatia: Can Consumer Bankruptcy Be One of the Solution?
}

\section{Dejan Bodul}

University of Rijeka, Faculty of Law, Chair of Civil Procedure Law, Croatia

e-mail:dbodul@pravri.hr

\section{Marko Tomljanović}

University of Rijeka, Faculty of Economics, Department of International Economics, Croatia e-mail: marko.tomljanovic@efri.hr

\begin{abstract}
System of social protection and security represent basis of social (welfare) state. In the operational-methodological context, it is about social security costs. One of the largest items refers to pensions, as the (largest) component of total expenditures for social benefits in all countries of the European Union, including the Republic of Croatia. The intention of this paper is not to enter into the analysis of the existing pension system, but to state that the pressure of pension payments due to the deteriorating ratio of employees and retirees has not bypassed the Republic of Croatia, which has resulted in new challenges and issues to be addressed. One of the questions, that is the main subject of the paper, is whether consumer bankruptcy as a measure with a social feature can compensate for the negative consequences of a larger number of pensioners and lower pensions in the situation that the elderly need to initiate it.
\end{abstract}

Key words: insured persons entitled to a pension, consumer-bankruptcy reason, consumer bankruptcy proceedings, discrimination. 